\title{
Expatriation in Chinese MNEs in Africa: An Agenda for Research
}

Terence Jackson and Frank M. Horwitz

\begin{abstract}
Despite increasing Chinese MNE activity there is a paucity of studies and critical analysis of expatriate management in Emerging Market Multinational Enterprises (EMMNEs). We argue that Chinese firms' expatriation policies and practices should be viewed in a different light to those of Western firms. We question whether Western modernization assumptions for emerging markets, often implicit within the international HRM literature, are appropriate when applied to Chinese MNEs. This has implications for the motivations of official Chinese policy regarding the presence of state MNEs in African countries, and individual Chinese MNE expatriation policies. Political-seeking motives may be moderated by an apparent disjuncture between Chinese official policy and individual firms' operational practices. Some potential synergies between Chinese and African cultural values are moderated by a low importance placed on the knowledge transfer role of Chinese expatriates and by the impact of the relational nature of career development including expatriate selection and an apparent low emphasis on pre-departure training. The main contribution of this work is to inform future empirical research at organizational level by making explicit differences in Chinese MNE engagement in Africa to Western MNEs, how this may influence expatriate policy and practices, and why this may contribute a different perspective to the extant expatriation literature. This article provides a critical evaluation of the current literature, theory and research, and identifies an agenda for expatriation research in the African context.
\end{abstract}

Key words: expatriation; emerging market multinational enterprises; China in Africa, international HRM, knowledge transfer, modernization theory. 


\section{Introduction}

Interest has moved from China as a huge market for Western MNEs towards the implications of China's 'going-out' policy as Chinese MNEs become major players on the world stage. Horwitz (2012) points to a focus in the literature on an increasing growth and investment relationship of an 'Afro-Asian nexus'. This is reflected in the volume of trade between China and African countries increasing exponentially since exceeding ten billion US dollars in 2000 and following the success of the Beijing Summit of the Forum on China-Africa Cooperation (FOCAC) in 2006, with African countries forming China's largest cluster of trading partners. More than one million Chinese, mostly labourers and semi-skilled workers have moved to the continent in the past decade (The Economist, January 17, 2015, p.49), and by 2007 there were over 800 Chinese companies in Africa (Schneidman 2007), of which at least 674 or $84.25 \%$ of these were state-owned enterprises (SOEs) (Alden \& Davies, 2006), increasing to an estimated 2372 in 2013 (MOFCOM, 2013).

Although knowledge is growing on Chinese MNEs in Africa, there remains a paucity of literature on the organizational-level engagement of Chinese MNEs in Africa and particularly on the nature of expatriation in Chinese firms. Of 24 articles in The International Journal of Human Resource Management since 1993 with 'Africa' in the title, only four mention 'expatriation, 'expatriate' or 'expatriates' in the body of the article, and none in the title or abstract (source: EBSCO/Business Source Complete). This dearth is a gap in knowledge, particularly with no benchmark for the study of Chinese expatriation in Africa and how it impacts on the performance of Chinese firms. Most Western literature on expatriation is based on knowledge of Western firms. This gap prevents further development of theories of expatriation from a wider international perspective. 
The article aims to build theory as a requisite for studying Chinese expatriation in Africa, focusing on the prevailing assumptions in the Western literature and why this may not be appropriate when applied to expatriation in Chinese firms in Africa. In particular, our objectives are to:

- Evaluate the assumptions of modernization theory in extant expatriation theory, and to question its relevance to Chinese expatriation in Africa, particularly in how knowledge transfer, knowledge sharing and mutual learning may differ in Chinese expatriation policy and practice.

- Examine the context and the nature of Chinese firms' operations in African countries, particularly in relation to possible conflicting motivations of Chinese MNEs and their relationship with Chinese expatriation policy and practice in Africa.

- Assess the relationship between official Chinese policy and practice and how this may affect (1) the relationship between expatriate and local staff and (2) the function of expatriation as a conduit for knowledge transfer and exchange. This is not to exclude other functions of expatriation, but to more fully explore an area that may differ from Western expatriation.

The nature of China's engagement with Africa is controversial, and a disputed area (Jackson et al, 2013). Yet it is important to examine these issues in order to develop an informed research agenda on Chinese expatriation. Considering the controversial and contradictory nature of the literature on China's engagement in Africa, we develop a number of propositions emanating from our literature review that identify issues to be addressed, and provide guidance for future research.

To achieve this the article examines existing knowledge of Chinese expatriation in the context of a growing body of literature on expatriation in emerging market multinational enterprises (EMMNEs) and how this applies to Chinese expatriation in African countries. It then examines the implications of this with regard to the 
effectiveness and appropriateness of Chinese management and operations in Africa, developing expatriation theory further in view of possible Chinese practices, and developing a research agenda.

The work is important in seeking to inform future research in this area, which can lead to a better understanding of Chinese firms' interaction with local employees and communities and the development of local economies, while contributing to the development of theories of expatriation in emerging economy MNEs specifically and expatriation theory generally. For the former, it is important to enhance scholarship that can ultimately point to policy on the implications of the nature of Chinese expatriation in African countries for the development of China as the largest emerging economy, and on the development of the host African country. We focus first on assumptions underpinning extant international management and HRM theory, and examine possible implications for the way expatriation may be conceived, particularly as a vehicle for knowledge transfer. Here, we propose, it is necessary to re-examine these assumptions in order to understand Chinese MNE expatriation policy and practice.

\section{International management studies and HRM}

A focus on Africa's development historically has been placed on modernization theory where the trajectory of development is presumed to be in the model of Western, developed economies (Jackson, 2012). This appears to be assumed, but not articulated, in international management studies when applied to 'developing' countries: Western management solutions are proposed to counter the perceived unproductive, inefficient and sometimes corrupt 'African' practices (Jackson, 2004, provides a critique). Such theories, when articulated in areas such as development economics, 'see advanced capitalist societies as models for all developing nations' (Kambhampati, 2004: 70). Particularly in international development such theory is problem-solving in the sense that it seeks to address the issue of how developing economies can progress from being traditional and poor, to become modern and rich. This also involves a perception that 
values should also change to reflect more 'modern' ideas including democracy and participation.

Stemming from the 1960s from ideas such as Rostow's (1960) 'stages of growth' theory, modernization theories have attracted criticism, being Eurocentric, seeing 'traditional' societies only in relation to 'modern' Western societies, failing to understand these societies and seeing 'modern' values diffused by education and technology transfer, mainly to the elites of 'developing' countries. Although submerged and not readily articulated, these assumptions are particularly prevalent in international management (including HRM) studies.

This conservatism, we suggest, is a hindrance to developing new and appropriate knowledge in the international context. A contribution of the current article is to question the assumptions underlying this thesis, and to examine how it might be inappropriate when studying Chinese expatriation in Africa.

Expatriation in Africa, within this thesis, can, in part, be seen as a vehicle for knowledge transfer (from West to East, or North to South), and therefore an agent for development: Western MNEs could therefore be seen as bringing advanced management, technology and technical skills to Africa predominantly through their expatriate employees. Yet within the literature knowledge transfer is not seen, of course, as the only function of expatriation (Ferraro, 2002; Harzing, 2001a, 2001b; Briscoe, 2015; Thomas and Inkson, 2007), nor is expatriation the only vehicle of Western management and technical knowledge transfer. Western-educated African management and technical employees and MBA-type courses as well as advanced technical courses in African higher educational institutions provide other vehicles and attest to the prevalence of Western management knowledge in Africa and other developing regions (Jackson, 2004). Within this context, what do Chinese expatriates bring to African countries that may be different to their counterparts in Western MNEs, and indeed, what do they take away with them from Africa, and what is their impact on Africa's (and China's) development? 
Knowledge transfer is not a one-way process. Theories of reverse diffusion (Zhang and Edwards, 2007) suggest that MNEs from emerging economies learn (through their expatriates) from operations in advanced economies by taking back knowledge learned in the host country to their home country. The theory suggests that this probably does not work conversely: MNEs from advanced economies do not take expertise back through knowledge learned in their operations in developing economies. Yet there has been much policy rhetoric from the Chinese government of mutual learning and friendship with African countries, and indeed a history of China in Africa quite different to the West's engagement (Brautigam, 2011), as well as possible greater cultural synergies between China and Africa (Jackson et al, 2013). This begs the question, what do Chinese MNEs, through their expatriates, take back to China from Africa through mutual learning and knowledge sharing, and what if any are the implications for China's own development? This is a question that is difficult to answer given the current literature. We focus more on the area of mutual learning which is a prerequisite of what Chinese expatriates take back to China. This occurs in a number of our propositions that we hope will inform a future research agenda. Mutual learning suggests knowledge sharing, rather than knowledge transfer: A theory of Chinese expatriation uncoupled from a Western modernization lens, should provide the possibility of mutual learning, knowledge sharing, and reverse diffusion.

In this way the nature of expatriation in a global South-on-South relationship may differ from that of a North-North or North-South relationship: the international HRM literature on expatriation may have gaps following more extensive research on emerging economy MNEs operating in other emerging markets. The current article aims to identify research propositions that could form an agenda for future research. We now examine the nature of Chinese MNEs engagement in Africa.

\section{Chinese MNEs in Africa}

To understand the nature of Chinese expatriation in Africa, it is important to assess conflicting evidence of how Chinese MNEs operate in African countries and why. 
There are two reasons why this is important. Firstly, assumptions that researchers might hold of China's motives as purely resource-seeking, has a direct consequence on the outcome of their research. This raises questions of the nature of knowledge in international management research, and how this is related to global economic and political relations (Jackson, 2012). Brautigam (2011) attempts to disabuse 'myths' in the media and some scholarly literature in international affairs around an assumption that China is the new imperialist power. She discusses how these are related to concerns of Western governments and international organizations that feel threatened by China's presence in Africa. It is important in any international management research to clarify such assumptions and to examine them critically.

Secondly there is a relationship between the nature of an MNE's international operations and how it uses expatriation to fulfill its objectives. This assumption goes back to Perlmutter's seminal work on modes of international operation (ethnocentric, polycentric, and regiocentric/geocentric) and their relationship to personnel practices (Heenan and Permutter, 1979; Perlmutter, 1984; Chakravarthy and Permutter, 1985). We postulate a relationship between the strategic intent and motivation of Chinese MNEs in Africa (in view of over 80 per cent being SOEs: MOFCOM, 2013), and HRM policies including expatriation practices and the perceived function of Chinese expatriation in these contexts. However, Cooke and Lin (2012) argue that:

'Chinese MNCs are heterogeneous in their scale, business nature, corporate competence, market opportunity and level of institutional support. They range from large state-owned firms which are going global with a political task to fulfil to small private firms driven by opportunity rent-seeking and short-term behaviour of their owners ill-equipped for international operations. These factors underpin their labour/HRM strategies that lead to diverse employment outcomes for those employed by the Chinese MNCs.' (Cooke and Lin, 2012, p. 221) 
This diversity notwithstanding, there is a preponderance of Chinese SOEs in Africa (Alden \& Davies, 2006; MOFCOM, 2013; Yi-Chong, 2014), and Cooke and Lin's (2012) assertion of SOEs' political intent would suggest a relationship between Chinese government policy, Chinese MNEs operational strategy and HRM practices including the nature of expatriation. However, this relationship between policy, operational strategy and HRM practices that we now investigate, is unlikely to be a straightforward one.

\section{Strategic motives of Chinese MNEs in Africa}

Interests and motivations of MNEs generally, and in the case of the current work Chinese MNEs in Africa in particular, are postulated by scholars as primarily resourcedriven given the continent's rich minerals, commodities and oil (Cheah et al 2014; Frynas \& Paulo 2007; Ping 2004). In particular, Parmentola (2011) argues that Chinese MNEs internationalize to acquire strategic assets and enhance competitive advantage. Yet Gugler's (2008) work identifies a mix of motivations that include market-seeking; resource-seeking; strategic asset-seeking and efficiency-seeking. China's interest does not appear to be solely in commodity-rich countries. This should be considered alongside evidence that growth in African economies is not limited to commodity-rich countries. An IMF study (The Economist, 2 November 2013) shows that eight of the 12 fastest growing economies in Africa do not rely on natural resources. Together these economies grew more quickly than the group of oil producers. Wei (2013) also finds that the interests of most Chinese MNEs and investors are not limited to natural resources but include market-size and potential for other commercial ventures in the value chain.

Cheah et al (2014) however, suggest that contemporary motives of China's 'going-out' policy are primarily market and resource driven and may be insensitive to and flout employee and property rights. From this perspective rather than past forms of politically motivated imperialist goals, these economic motives have been considered as 'neo- 
colonial' or a new form of 'colonialism' perpetuating underdevelopment in developing countries (Corkin and Naidu 2008).

Pertinent to expatriation policy and practice, this so-called new mode of 'colonialism' in emerging markets has been associated with new forms of economic resource and social exploitation based on commodity and energy needs of high economic growth investing countries such as China, and appears more concerned with Chinese expatriate deployment than local human resource development, skills transfer and employee rights in local labour markets. Hence, Wilkinson, Wood and Demirbag (2014) note that Chinese MNEs in African countries such as South Africa and Zambia deploy both expatriate semi-skilled and unskilled workers in spite of the availability of local labour. A more balanced approach to understanding the motivation of Chinese MNEs in Africa can be taken from Gill, Huang and Morrison (2007) who believe that China needs Africa for: resources to fuel China's development goals; markets to sustain its growing economy; and for political alliances to support its aspirations to be a global influence. Although the mix of motivations identified by Gugler's (2008) may be held in common with Western firms, there appears to be a difference in that this third motivation of Gill, et al (2007) may substantially reduce the effect of China's intent as purely resourceand market-seeking. This may particularly be the case as the majority of Chinese MNEs appears to be SOEs (Alden \& Davies, 2006; Yi-Chong, 2014) as stated above. Yet this political motivation may also be different in substance as well as in influence.

For many Western scholars China's interest in Africa goes beyond the continent's wealth of resources and includes human resource, political and diplomatic aspects (Gill and Reilly, 2007), i.e. the notion of 'political-seeking'. According to China's Africa policy issued in January 2006, China will:

'carry forward the tradition of China-Africa friendship, and, proceeding from the fundamental interests of both the Chinese and African peoples, establish and develop a new type of strategic partnership with Africa, featuring political 
equality and mutual trust, economic win-win cooperation and cultural exchange' (MOFA, 2006).

Cultural communication between Africa and China, according to King (2006), appears to celebrate Africa's culture and achievements, while these are implicitly denigrated in the West, seeing Africa as backward and in need of liberalization and democratization (Jackson, 2004). This, along with China's involvement in Africa's anti-colonial efforts, may indicate a different type of relationship. Shinn (2006) suggests that African governments and ordinary Africans regard China as more responsive to African needs than are the models presented by the West. This may suggest a relationship of mutual learning, which may have implications for the way Chinese expatriation should be investigated and may, at least in theory, require a range of different skills such as diplomacy from senior Chinese expatriates in Africa. Hence, the official Chinese policy appears to be non-interference in Africa's governance, and one of mutual learning, stemming from a history of anti-colonialism.

If policies of 'friendship and mutual' learning filter down to individual Chinese MNEs operating in Africa (given the majority are SOEs) it is likely that this will reduce the importance of the motives purely for resource-seeking and market-seeking, with a resource-seeking motive suggesting low levels of engagement with local employees and communities. Despite a lack of literature in this area there does appear to be evidence that Chinese expatriates often live in separate compounds and have minimum interactions with locals (Brautigam, 2011). Where firms are more market-seeking, there is a likelihood that more expatriate interaction with local communities will be needed in order to create and nurture those markets. More pre-departure training will be desirable. Requirements for interactions with locals will be more necessary when there is an intent towards mutual learning and cooperation through a predominant politicalseeking motive. 
However, to add to this contested area of the motivation of Chinese MNEs in Africa, Jackson (2014) has suggested there may be a 'strategic/operational divide', or a disjuncture between Chinese governmental policy and involvement at strategic levels, and what happens in individual MNEs at operational levels. We now examine this possibility.

\section{Disjuncture between Chinese strategic policy and MNE HR operations}

Although Chinese policy professes mutual learning between China and African countries, Jackson (2014) suggests this is reflected at a wider community level in providing opportunities for upskilling and capacity building through educational projects such as teacher training and technical and scientific training, but there is little evidence that this is happening at organizational levels in individual MNEs, and little evidence of upskilling in specific work organizations. There is evidence of job creation in areas of few opportunities for local employees, but at individual organizational level employment conditions are often poor. This appears to imply that there may be little connection between Chinese policy, MNE motivation and intent and HRM/expatriate practices. This is likely to be more so with private commercial firms, where the diversity of Chinese MNEs in Africa should be taken into account. Not only is there likely to be more of a disconnection between Chinese policy and operational practices of non-SOEs and hence a lower political-seeking motivation, the market-seeking motivation together with a resource-seeking motivation is likely to be more acute as it will not be moderated by motives of friendship and mutual learning. These issues need investigation in any research agenda, together with the connection between these three motives of Chinese MNEs, HRM and expatriate policies and practices, and can be encapsulated in the following propositions that need examining in future research.

Proposition 1: With most Chinese MNEs in Africa being SOEs, the Chinese policy of 'friendship and mutual learning' is associated with: 
1.1. higher levels of engagement with both local employees and communities

1.2. higher level training and pre-assignment orientation including both selection and training in diplomacy skills, language and cultural knowledge.

However, considering the diversity of Chinese MNEs that Cooke and Lin (2012) alluded to, although non-SOEs may only make up as little as 16 per cent in Africa (Alden \& Davies, 2006), though this may be growing (MOFCOM, 2013), the following should also be investigated in future research:

Proposition 2: 2.1. There is a gap between the political seeking of Chinese government policy and individual MNEs' HR and expatriate management policies and practices. This applies particularly to non-SOEs.

2.2. Stronger resource- and market-seeking motives lead to fewer opportunities for local employees, less mutual learning and knowledge sharing, and less predeparture preparation for Chinese expatriates.

With an assumption that many Chinese MNEs in Africa will be influenced by official government policy, a concomitant of this apparent 'friendship' orientation or intention of Chinese MNEs, may be the closer synergies between Chinese and African cultural values, which again holds the possibility of engendering mutual understanding, and reinforcing political motivations of cooperation and friendship.

\section{Chinese and African Cultural Synergies}

The Chinese value of ren (humanity) (Ip, 2009) appears close to the African value of ubuntu (humanity) (Mbigi, 1997). Ip (2009) points out that the Confucian concept of the person is essentially a social one, through familial collectivism. The person is defined by his or her relationships. A person's identity cannot be understood as 
something separate from his or her social attachments and place in the hierarchy of social relationships. A person is shaped by this social embeddedness in terms of their interests and goals, and also constrained by the same relationships. The social bonds thus created are a source of indebtedness and obligations. This explains well the modern day version of Confucian relationalism': guanxi according to Ip (2009: 465). This appears similar to the communalism of African cultures and contrary to Western individualistic cultures that may be at variance to African community cultures (Jackson, 2004, Horwitz \& Budhwar 2015).

Yet the possibility exists that ren does not apply to African employees as members of outgroups and not part of Chinese guanxi; and Chinese managers and employees are outgroup members as far as African ubuntu is concerned. However, Mutabazi (2002) points out that his research indicates $u b u n t u$ does apply to outgroup members (strangers to African communities). Exploring the cultural synergies between Chinese expatriates and local staff and the implications of this for mutual understanding should form an important part in a research agenda in this area. Hence we propose:

Proposition 3: Cultural synergies, involving shared values of humanity, relationalism and communalism, between Chinese expatriates and African employees strengthens (the political motive of) friendship and cooperation and engender mutual cooperation and learning at organizational level.

However, for these synergies to be useful for the interaction between Chinese managers and African employees, this would presume the acquisition of cultural knowledge by Chinese expatriates prior to leaving their home country. It would need to be incorporated within expatriate training and orientation. There is evidence from Shen and Edwards (2013) that this is not happening. Yet there also remains in the literature contra-indications regarding Chinese nationalism (Dikkoter, 1994; Jacques, 2009) and racism (Shen, 2009) that may need investigation in terms of Chinese expatriates 
attitudes towards African local employees. Such attitudes may directly affect expatriates interactions with local employees, and should form an integral part of future research.

We now turn to the implications for Chinese expatriation that we have alluded to in the previous sections and our propositions. Here our main focus remains on SOEs as the overall majority of Chinese MNEs in Africa.

\section{Chinese MNE expatriation}

Although there is a growing literature at the macro levels that examines Chinese motives and strategies, little of this literature really relates to the firm level in Africa. This section explores the literature and draws out implications for Chinese expatriation. It looks at the relationship between Chinese expatriates and local employees, and with the local community. One of the contentions in the literature is that Chinese firms bring all their own staff, and therefore all their employees are expatriates. This is challenged by Bräutigam's (2011) empirical findings and Baah and Jauch's (2009) study across a number of African countries offering empirical data from a labour relations perspective. Literature suggests that Chinese expatriates in Africa are managerial and technical staff, with few expatriates at operational level except in oil rich countries where local staff is expensive (Brautigam, 2011). There appears little skills transfer between expatriates and local unskilled staff, and little interaction between expatriates and local communities except for recruiting staff (Jackson, 2014). There is also little evidence that reverse diffusion happens from African country operations (learning from Africa and taking it back to China), but the converse of expatriates not transferring skills and knowledge with local employees and African partners may be an area for concern in terms of longer-term servicing of projects, and generally for Africa's development.

One of the main benefits drawn from the Chinese presence in Africa appears to be the creation of local jobs (Bräutigam, 2011). Logically this would indicate a degree of upskilling to enable locals to do these jobs in line with the firm's (that is expatriate 
managers') expectations. This would involve transferring at least rudimentary skills and knowledge, and also some part of the norms, practices and values of the firm (i.e. the Chinese firm's culture). It would also appear to suggest that Chinese expatriate senior managers would have appropriate experience to recruit employees at local level and an element of local knowledge, or the buying-in locally of personnel management with the necessary skills and local knowledge, including knowledge of local employment law and relevant institutions.

The former would necessitate training in this area prior to leaving China. The latter would provide evidence of Chinese MNEs employing highly skilled local employees. Much available literature on Chinese expatriation and MNE operations generally, focuses on differences between 'developed' and 'developing' country operations, e.g. Shen (2007) and the role of expatriation; and, the role of expatriates, e.g. the apparent lack of transfer of skills/knowledge to local employees, and differences between developed and developing country operation in reverse diffusion (Zhang and Edwards, 2007).

\section{Chinese expatriation and career development: selection and competencies of Chinese expatriates}

Shen and Edwards (2013) shed light on the impact of internationalization and globalization on Chinese MNE recruitment and selection, training and development, performance appraisal, reward and compensation, international employment relations and the strategic integration of HRM policy and practice, and provide some insight in the way expatriation is used in career development. This work critically assesses reasons for expatriate failure. These include in certain Chinese MNEs inadequate selection and expatriate recruitment. Short-term two-year expatriate contracts are used in most instances. This occurs in order to reduce the prospect of the Chinese expatriate seeking to leave the employer and remaining permanently in the host country. 
Shen and Edwards (2013) found that no attention was paid to criteria such as cultural empathy, initiative and creativity and emotion stability or maturity, nor family situation: areas well covered in the literature on Western MNE where these factors are viewed as important. Their study found that family-related and personal problems were the primary reasons for expatriate failure. Spouses are rarely interviewed regarding a prospective international assignment. International performance management and expatriate selection tend to focus on the 'hard', technical factors rather than on the 'soft variables' of cross-cultural intelligence and emotional intelligence, again an area that has been extensively explored in the context of Western MNEs expatriation practices (Lee and Sukoco, 2010). Relatedly, Shen and Edwards (2013) found that Chinese MNEs have a strong preference for internal recruitment and promotion and prefer a 'pre-selection' process to openly advertising posts, practices that might be regarded as nepotism in the context of Western MNEs (Jackson, 2011). Hence:

Proposition 4: Selection of Chinese expatriates for assignments in Africa, is more strongly evidenced by the internal standing of the candidate in the Chinese MNE through technical and managerial skills and seniority, than cultural empathy, relational skills and family adjustment. This is associated with expatriates being ill-equipped to interact with locals at work and in the community with a detrimental effect on mutual learning.

Studies by Kupka, Briscoe, Everett (2013) and Wang et al (2013) found that conscientiousness and openness were valuable to the development of cross-cultural competencies in Chinese expatriates, though this also holds for managers from developed market MNEs. These researchers observe that there are cultural and institutional differences between China and host countries that tend to constrain the ability of Chinese expatriates to influence their host-country employees. Jie (2010) and Qi (2012) found Chinese MNEs more likely to use talent localization rather than expatriates in certain countries although in Africa there is a stronger tendency to deploy 
Chinese expatriate managers and workers (Kupka, Briscoe and Everett (2013); this being largely due to institutional and cultural factors as well as a lack of Chinese experience and language differences resulting in a lack of trust with local partners and lack of integration between expatriates and local employees (Gao, Liu and Lioliou, 2015; Cooke, 2011; and Nankervis et al, 2014).

Our assertions earlier that there may be some synergies between Chinese and African cultural values appears not to be a feature in these studies, and may show an ignorance of such possible synergies among Chinese expatriates. This may be exacerbated by the language deficiency of Chinese expatriates in Africa identified by Baah and Jauch (2009). This lack of integration with host country employees is explained by Gao et al (2015) as a combination of hierarchal organisation structures in many Chinese state owned enterprises (SOEs) and cultural exclusion from the expatriate trust circle, and by Wei and $\mathrm{Wu}(2015)$ as reflecting 'institutional and cultural distance'. Given the need to balance different MNEs' motives of resource-, market- and political-seeking discussed above it is proposed:

Proposition 5: Chinese expatriates have inadequate pre-departure cultural training sufficient to equip them to balance the different needs of the MNE in Africa. This has a negative effect on the relationship between expatriates and locals that militates against mutual learning.

\section{Expatriation and management control: deployment of Chinese expatriates}

Insight is provided into the nature of expatriation as control in international assignments by Shen and Edwards (2013) who found that Chinese MNEs were generally reluctant to place host country nationals $(\mathrm{HCN})$ in key managerial positions or to train and develop HCNs for upward mobility. They concluded that Chinese MNEs tend to adopt an ethnocentric rather than polycentric staffing approach (Shen and Edwards, 2013). They found that most Chinese MNEs assign more expatriates to senior positions in international subsidiaries than US and European MNEs. Unlike many Western MNEs 
those from China appear to 'discriminate in their approaches to different nationalities and employees in different positions' (Shen and Edwards, 2013: 56). The cultural construct of guanxi appears to plays a relevant part in HRM policy and practice and applies predominantly to parent country nationals (PCNs). Hence:

Proposition 6: Chinese MNEs in Africa rely on expatriates for senior staffing. This reduces promotion prospects and direct recruiting of local employees for senior positions. This militates against higher levels of managerial mutual learning and development.

\section{Expatriation and management control: balancing centralization and decentralization}

The various international HRM processes referred to here tend to occur in an organizational configuration of duality or a dualistic approach to centralization and decentralization of international HRM (Shen and Edwards (2013). Chinese MNEs are generally centralized in expatriate and executive management including $\mathrm{HCN}$ executives. They are more decentralized regarding training, performance appraisal and employment relations. From this research, there seems to be little international HRM integration in Chinese MNEs (Shen and Edwards, 2013). Given Jackson's (2014) assertion of a strategic/operational divide noted above:

Proposition 7: Senior Chinese expatriates in MNEs in Africa have a high level of autonomy regarding local employment issues. This is associated with a strategic and operational divide between Chinese MNEs policy intent and local decisions in MNE subsidiaries. This in turn is associated with variation among MNEs in levels of expatriate-local interaction and mutual learning and development. 
Shen et al. (2005) further highlight the dilemma in the minds of decision-makers in Chinese MNEs with regard to convergence and divergence of HR practices in their global operations. On the one hand, they realize that their home country HRM systems may not be readily transferable because they are only applicable in the unique context of the Chinese economic, political and social system, yet they are reluctant to give total freedom to subsidiaries to adopt local practices for fear of losing control (Shen et al. 2005). Also, they tend to adopt ethnocentric staffing approaches in the initial phases of internationalization because of their inability to attract top talent in the host countries and reluctance to provide training and development opportunities for host country nationals. This can result in a 'lack of identification from local (non-Chinese) employees with the employer' (Cooke 2011:23).

In terms of future challenges in emerging markets, Teagarden and Cai (2009: 79) note that Chinese multinationals 'must all continue to build their leadership pipelines, embrace succession planning, and master talent management in multiple labour markets, not just at home'. Cooke (2008) observes that in general, Chinese managers still lack foreign market knowledge, experience and international expertise. They also have insufficient understanding of host countries' employment legislation and characteristics of labour relations, particularly the different attitudes towards trade unionism. Managing international human resources does seem to be a weakness rather than strength in most MNEs from the BRICS countries according to Thite (2015). He finds that challenges for Chinese MNEs in this regard are multi-faceted. Teagarden and Cai (2009) also note that Chinese MNEs find global talent management difficult, particularly in economies that are different to their own. Hence:

Proposition 8: In managing the balance between integration and differentiation in global Chinese MNEs, a low level of understanding of local conditions and an unwillingness to relinquish centralized control are associated with (1) a lack of identification with the company by local employees and (2) poor expatriate and local staff HR communication. This militates against mutual learning and development. 
In this section we summarized the literature relevant to an informed discussion of Chinese expatriations in Africa, and have suggested from this research propositions that could be tested in future empirical research. We have examined the relevant literature on Chinese expatriation touching on its functions of career development and control, while focusing on the implication of these on expatriate-local interaction and mutual learning in the light of China's professed policy of friendship and cooperation, and emphasized the political-seeking motives of Chinese MNEs in Africa.

Evidence suggests that a number of factors, including the nature of Chinese expatriation, militate against this motive being fully realized in individual MNEs although it seems likely that there is variation among MNEs. We now examine how we might build on this literature in order to further develop scholarship in this area.

\section{Theorizing Chinese expatriation in Africa}

We have suggested that extant international HRM theory, including theory of expatriation, is implicitly informed by modernization theory. It is also informed more explicitly by theories encapsulated in the idea of people as resources: one which Jackson, $(2002 ; 2004)$ has argued is culture-bound and often not appropriate in nonwestern cultural context. Both these underlying assumptions have implications for the way Western scholars have conceptualized expatriation, and the way Western MNEs have tended to operate in 'developing' regions such as Africa. We now discuss how these assumptions may be dealt with in further developing a more critical theory of expatriation.

\section{Expatriation and knowledge transfer}

A major aspect of expatriation in extant theory is that of knowledge transfer largely from MNE headquarters to subsidiaries through mediation of expatriates' competencies, and the absorptive capacity of the subsidiary (Chang, Gong and Peng, 2012). Absorptive capacity is 'the ability to recognize the value of external knowledge, 
assimilate it, and apply it to subsidiary operations' (Cohen and Levinthal, 1990: 128). This is a key aspect in expatriation theory with expatriation as a proxy for knowledge transfer in a number of studies concerning subsidiary performance (Chang, Gong and Peng, 2012). Bonache and Zarraga-Oberty (2008:7) go further in asserting that 'absorptive capacity of a local unit resides with its employees', adding that poor prior knowledge and motivation of local staff will restrict knowledge transfer.

In the absence of empirical studies that focus on African staff in this context, general literature on management and HRM in Africa suggests a pejorative view of both 'African' organizational capacity as well as the capacity and motivation of African staff (Jackson, 2004). In terms of knowledge transfer and absorptive capacity this is reflected in studies such as those by Osabutey, William and Debrah (2014) and Kamoche and Harvey (2006), which suggest that weaknesses in infrastructure in Africa restrict experiential learning and absorptive capacity. Hence there is general denigrating of such capacity under an assumption that 'modern' management methods, transferred in by Western MNEs through their expatriates, are appropriate to the African context.

Through further empirical research on Chinese expatriates attitudes towards African employees, it could be determined how this influences knowledge transfer (and indeed knowledge sharing); and whether this differs to the strategic intent of (particularly stateowned) MNEs executives in terms of government policy of friendship and mutual learning. It is possible to theorize this through an understanding of the cultural synergies discussed above, but also through an understanding of constraints such as a lack of predeparture orientation and training (Shen and Edwards (2013) and language issues (Baah and Jauch, 2009). Evidence suggests that China's engagement with Africa has been one of non-interference in issues such as governance and economies in contradistinction to Western governments conditionality attached to aid (Jackson, 2012); and by the reported lack of transfer of knowledge and skill to local employees by Chinese expatriates (Lee, Wang and Liu 2013, Jackson, 2014). The latter occurs notwithstanding findings from case study research that certain Chinese MNEs such as 
Huawei have 'sophisticated staffing, human resource development, performance management and reward systems' (Nankervis et al 2014:121). Although this apparent indifference may be criticized (supporting governments that infringe human rights; failure to upskill and promote local staff), it may also be indicative of a lack of modernizing ethos in many Chinese MNEs, and a major difference to the value assumptions underlying Western expatriation.

In terms of a theoretical proposition we posit that:

Proposition 9: Chinese expatriation holds lower assumptions of modernization associated with a lower level of unidirectional knowledge transfer from expatriates to local staff, and higher levels of two-way knowledge exchange and mutual learning.

This differs from the underlying assumption of Western expatriation that can implicitly view management, organization and technology in Africa, and other emerging regions, as developing and in need of modernization.

\section{Expatriation, cultural synergies and human resources}

The reporting in the literature of a lack of selection and specific training for expatriates may also represent a departure from expatriation theory based on Western MNE assumptions and practices. The valuing of people in organizations as resources appears to be an underlying value and assumption in Western HRM theory, which Jackson (2002a) has pointed out may not readily transfer to other cultural contexts including China, and also likely not to African cultural contexts (Jackson, 2004). Jackson (2002b) further pointed to the connection of this instrumental valuing of people in organizations to the competencies approach in Western HRM. Hence operational objectives lead to the identification of a list of competencies that forms the basis of recruiting (often strangers), training, and reward within organizations. These competencies and individual results achieved by staff form the basis of their value to the organization 
(Jackson, 2002b). More humanistic values that underpin many non-Western societies look more at the intrinsic value of a person often as part of a community group. This appears to be the case in the Chinese and African cultural contexts. Selection and training based on instrumental assumptions may not therefore be appropriate in these contexts, and perhaps not for Chinese expatriates. To interpret this apparent lack of due selection process negatively may be a cultural misconception. Yet the efficacy of the approach taken by Chinese MNEs in selecting and preparing their expatriates for assignments in Africa must also be taken into account, although may require a different set of assumptions and criteria to analyze this. Hence:

Proposition 10: Chinese cultural assumptions underpinning expatriation decisions, based on relational and humanistic values (rather than instrumental values) regarding human resources, are associated with selection processes based on relational choices than on specific competencies-based formal expatriate preparation.

This may, however, represent the tip of the cultural iceberg. Understanding the nature of Chinese cultural values that are actually taken to Africa by expatriates, the levels of cultural synergies between Chinese and African (and differences in the numerous African countries in which Chinese MNEs operate), as well as the level of mutual understanding of cultural synergies and differences, and how these factors manifest in expatriate-local interaction can currently only be speculated. Yet it is possible to outline an appropriate conceptual model in order to start to empirically investigate these issues from the assumptions and variables presented so far.

\section{Towards a conceptual model of Chinese MNE expatriation in Africa}


From the above discussion and literature review it appears that there are key factors that impact on Chinese MNE expatriation that may distinguish it from Western MNE expatriation (Figure 1).

Figure 1 about here

The first factor is the lack of a modernization assumption that logically may lead to a low expectation of knowledge transfer as discussed above. Chinese official policy of friendship and mutual learning could lead to an assumption of knowledge sharing, yet there appears to be a strategic/operational divide between professed governmental strategy and what happens at the operational level of the individual MNE. Although there appears to be an emphasis on the political-seeking motive of Chinese MNEs through government policy (which may not be reflected at individual MNE level), it seems likely there is a connection between this low assumption of knowledge transfer and low pre-departure preparation. With the career related aspects of selection and deployment of expatriates based on relational aspects, where the internal standing of the member of staff is paramount together with technical abilities, preparation for cultural, empathy and social aspects appears not relevant, as little transfer of skills is assumed, and developing absorptive capacity of the African subsidiary is not a factor. Indeed, with senior positions occupied by expatriates, there appear few promotion prospects for local employees, and developing local employees to enable knowledge transfer is not a priority.

Although we discussed above a hypothetical connection between a resource-seeking motivation and low levels of expatriate engagement and low levels of orientation needed (Figure 1), we propose that it is the lack of a modernization and knowledge transfer assumption (often assumed in Western expatriation in emerging countries) that is paramount in determining the levels of expatriate engagement with local staff. A 
corollary of this in the political sphere is the low modernizing ethos of Chinese government agencies in African countries where Western governments accuse the Chinese of ignoring human rights issues, and the lack of conditionality of aid to African countries discussed above. This is only an issue when modernization is assumed in working with emerging economies.

The second factor that appears important in Chinese MNE expatriation in Africa concerns Chinese cultural values (Figure 1). We have already mentioned in this section the connection between the relational aspects of such values and expatriate selection and deployment. In this, together with the humanistic aspects of the Confucian value of ren (and guanxi), we have suggested a synergy with the relational and humanistic African value of ubuntu. Yet there is a paradox created by the low levels of predeparture preparation and low value placed on cultural empathy skills (in part because of Chinese relational values, and also a low modernizing ethos) that any synergies existing are not recognized and therefore not positively channeled by Chinese expatriates as they have not got the necessary skills and knowledge.

This is moderated by a third factor that concerns management control, an apparent issue in Chinese MNEs with managing the tensions of centralization versus decentralization (Figure 1), particularly problems that Chinese MNEs have experienced in managing integration/differentiation. This appears to be associated with local autonomy on employment issues, reinforcing a strategic/operational divide, lack of local knowledge and managing tensions between expatriate and local employee deployment.

Extant international HRM theory assumes a modernization ethos, which appears not to be present when Chinese MNEs operate in emerging countries. Relating to the notion of an 'Afro-Asian nexus' (Horwitz 2012:2938) in HRM, cultural similarities that China may have with other emerging market contexts, though under-explored and often unarticulated, is also a variable to be considered particularly in Chinese expatriate development and the development of HCNs. 


\section{Conclusions and implications for research and practice in Chinese MNEs in Africa}

The main aim of this article is to point to future research of Chinese MNE expatriation, not just in Africa, but also with implications for other emerging markets in which Chinese firms operate. We have suggested this requires a shift in the way expatriation is conceptualized, as assumptions made in management scholarship in the International HRM literature may be inappropriate when applied to Chinese MNEs. It also applies to potential synergies between Chinese cultural values and those of other emerging markets moderated by a low importance placed on the knowledge transfer role of Chinese expatriates and the impact of the relational nature of career development including expatriate selection.

By developing a theoretical model in the previous section and informed by a number of exploratory propositions derived from our literature review we have pointed to key areas that should form part of future research. Hence, investigating the motivation of Chinese MNEs is a prerequisite in contextualizing expatriation (propositions 1 and 2), yet assumptions of Chinese firms' motives based solely on resource- and marketseeking (China as new imperialist) is questionable. Research should investigate the moderating influence of China's political-seeking motives (proposition 2) taking cognizance of the work of Gill and Reilly (2007), and being aware of a possible strategic/operational divide identified by Jackson (2014). We have argued that Chinese firms' motivations have an influence on the levels of expatriate engagement and the levels of orientation and pre-departure training (proposition 1), and this needs further empirical investigation. Yet this simple relationship is likely to be moderated by the nature of expatriate selection through the internal standing of the candidate as a result of cultural relational values (proposition 5) and the connection of this with expatriate success, as well as awareness of cultural synergies. Similarly, a simple linear connection between cultural closeness and expatriate success cannot be assumed (Gong 
2003). This needs further investigation building on the work of Shen and Edwards (2013).

Similarly, Chinese expatriates do not appear to acquire basic cultural awareness skills through pre-departure training (proposition 5). This training linked with the motivation of Chinese firms in Africa and other emerging markets (propositions 1 and 2) needs further empirical investigation. A starting point for such investigation is the relationship between levels of training and skills, and the nature of China's engagement in Africa, looking first at the extensive study of Baah and Jauch (2009) across African countries. Further, Shen and Edwards (2013) point to the lack of opportunity for local staff with Chinese expatriates occupying senior position (proposition 6). The connection between this, cultural relational values (proposition 10), and a lack of modernizing ethos (proposition 9) should be investigated (Figure 1 shows these proposed connections). This lack of opportunity and training of local employees may be a result of the strategic/operational divide hypothesized in proposition 5, and derived from the level of local autonomy afforded senior Chinese expatriates in terms of local employment issues (proposition 7). Again, these connections (Figure 1) need to be investigated in future research, together with the difficulty Chinese MNE management has with managing differentiation/integration issues (proposition 8), identified by Shen et al (2005).

Despite increasing attention being paid in the literature to EMMNEs, little relates to expatriation, particularly concerning operations of Chinese MNEs in other emerging markets such as Africa. Where literature does exist, there still appears to be an overreliance on expatriate theory derived predominantly from Western MNE operations and practices. Notions of knowledge transfer for example, by MNE expatriate to subsidiaries in emerging markets cannot be inferred and generalized from extant literature. A direct relationship between levels of centralization/decentralization and integration/differentiation and the way expatriation is managed within an MNE cannot be assumed when looking at Chinese MNEs, as other factors such as a low assumption of knowledge transfer and up-skilling of local workers may have a substantial influence 
on the nature of MNE organization and management, and HRM practice. These aspects are absent from current expatriation theory and need to be incorporated through more extensive research of Chinese MNEs in African and other emerging markets. The current article makes an important contribution in pointing the way for further work by challenging current assumptions and identifying areas for further research.

\section{References}

Alshahrani, A. T., and Morley, M (2015). 'Accounting for variations in the patterns of mobility among conventional and self-initiated expatriates' International Journal of Human Resource Management, 26(15): 1936-1954.

Baah, A. Y. and Jauch, H. (eds.) (2009) Chinese Investments in Africa: A Labour Perspective, Johannesburg: African Labour Research Network.

Bader, B. (2015). 'The power of support in high-risk countries: compensation and social support as antecedents of expatriate work attitudes'. International Journal of Human Resource Management, 26(14-14): 1712-1736.

Bonache, Jaime, \& Zarraga-Oberty, Celia. (2010).' Determinants of the success of international assignees as knowledge transferors: a theoretical framework.' International Journal of Human Resource Management, 19(1), 1-18.

Black, J.S and Mendenhall, M. (1990). 'Cross-cultural effectiveness: A review and theoretical framework for future research'. Academy of management Review, 115: 113-136.

Boyacigillar, N. (1990). 'The role of expatriates in the management of Interdependency, complexity and risk in multinational corporations.' Journal of International Business Studies, 21: 265-273.

Briscoe, D.R. (2015). 'Expatriate integration and performance in emerging markets'. In Horwitz, F.M., and Budhwar, P. (Eds). Handbook of Human Resource Management in Emerging markets. Edward Elgar Publishing, Cheltenham United Kingdom \& Northampton MA USA, pp. 150-172. 
Briscoe D.R., Schuler, R.S., \& Tarique, I (2012). International Human Resource Management ( $4^{\text {th }}$ edition) Routledge: London/New York.

Brewster, C., Mayrhofer, W., \& Cooke, F. (2015). 'Convergence, divergence and diffusion of HRM in Emerging markets'. In Horwitz, F.M., \& Budhwar, P. (Eds) Handbook of Human Resource Management in Emerging Markets. Edward Elgar Publishing, Cheltenham UK \& Northampton MA. USA pp. 451-469.

Brewster, C., and Mayrhofer, (2012) (Eds). Handbook of Research on Comparative Human Resource Management, Edward Elgar Publishing: Cheltenham UK \& Northampton MA. USA.

Brewster, C., Mayrhofer, W., and Morley, M. (2004) (Eds). Human Resource Management in Europe: Evidence of Convergence? Oxford: Elsevier/Butterworth-Heinemann. Bräutigam, Deborah (2011) The Dragon's Gift: The Real Story of China in Africa, Oxford: Oxford University Press.

Budhwar, P., and Debrah, Y. (2001) (Eds), Human Resource Management in Developing Countries. London/New York: Routledge.

Caligiuri, P.M. (1997). 'Assessing expatriate success: Beyond just being there.' New Approaches to Employee Management, 4:117-140.

Chakravarthy, B. S. and Perlmutter, H. V. (1985). 'Strategic planning for a global busines'., Columbia Journal of World Business, 1985, Summer, 3-10.

Chang, Y-Y, Gong, Y and Peng, M W (2012). 'Expatriate knowledge transfer, subsidiary absorptive capacity, and subsidiary performance'. Academy of Management Journal, 55(4), 927-49.

Cheah, J., Mazouz,K., Yin,S., and Wood, G. (2014). 'Foreign direct investment to AfricaThe HRM Context'. Human Resource Management, 147 pp; forthcoming.

Cohen, W M and Levinthal, D A (1990). Absorptive capacity: a new perspective on learning and innovation, Administrative Science Quarterly, 35, 128-52.

Cooke, F.L. (2008). 'Enterprise culture management in China: An insider's perspective'. Management and Organization Review, 4, 2:291-314. 
Cooke, F.L. (2011). 'The globalization of Chinese telecom corporations: Strategies, challenges and HR implications for MNCs and host countries'. International Journal of Human Resource Management, 001.10.1080/095885192.2011.579920, p.23.

Cooke, F.L. and Lin, Z. (2012), 'Chinese firms in Vietnam: Investment motives, institutional environment and human resource challenges', Asia Pacific Journal of Human Resources, 50, 205-226.

Collings, D.G, and Scullion, H. (2012). 'Global Staffing'. In G.K. Stahl., I. Bjorkman, and S. Morris (Eds). Handbook of Research in International Human Resource Management, Cheltenham, UK and Northampton MA. USA: Edward Elgar Publishing, pp.142-161.

Corkin, L., \& Naidu, S. (2008). 'China and India in Africa: An Introduction'. Review of African Political Economy, 35 (115), pp. 115-154.

Dikkoter, F.(1994). 'Racial identities in China: context and meaning'. China Quarterly, 138: 404-12.

Edwards, C., and Zang, M. (2003). 'Human resource management strategy in Chinese MNCs in the UK'. Research and Practice in Human Resource Management, 11(1): 1-14.

Ferraro, G. (2002). Global Brains: Knowledge and Competencies for the $21^{\text {st }}$ Century. Charlotte, NC: Intercultural Associates.

Frynas, J.G., and Paulo, M. (2007).'A new scramble for African oil? Historical, political and business perspectives.' African Affairs, 106 (423), pp. 229-251

Gao, L., Liu, X., and Lioliou, E. (2015). 'Dynamic capabilities, managerial mindsets and the outcomes of internationalization: the case of Chinese state-owned enterprises'. In Demirbag, M, and Yaprak, A. (Eds). Handbook of Emerging Market Multinational Corporations. Cheltenham: Edward Elgar Publishing, pp. 198-221. 
Giese, K and Thiel, A. (2015). 'The psychological contract in Chinese-African informal relations'. International Journal of Human Resource Management, 26(14): 1807-1826.

Gill, B. Huang, C-h \& Morrison, J. S. (2007). 'Assessing China's growing influence in Africa'. China Security, 3(3), 3-12

Gill, B. and Reilly, J. (2007). 'The Tenuous Hold of China Inc. in Africa'. The Washington Quarterly, 30:3 pp.37-52;

Gomez, M., Cohen, M., and Mellahi, K (2013). 'When two African cultures collide: A study of the interactions between mangers in a strategic alliance between two African organisations'. In Newenham-Kahindi, O., Kamoche, K, Chizema, A and Mellahi A. (2013) (Eds) Effective people Management in Africa. London: Palgrave Macmillan, pp. 180-201.

Gong, Y. (2003). 'Subsidiary staffing in multinational enterprises'. Academy of Management Journal, 46: 728-739.

Gugler, P. (2008). 'Chinese companies worldwide'. Vo. Accessed online 29 October 2013 from http://www.voxeu.org.aricle/how-are-Chinese-multinationalentrprises-different?

Harvey, M., Speier, C., \& Novecevic, M.N. (2001). 'A theory-based framework for strategic human resource staffing policies and practices'. International Journal of Human Resource Management, 12: 898-915.

Harzing, A-W. 2001a 'An analysis of the functions of international transfers of managers in MNCs. Employee Relations, 23: 581-598.

Harzing, A-W. 2001b. 'Of bears, bumblebees, and spiders: The role of expatriates in controlling foreign subsidiaries'. Journal of World Business, 36(4): 336-379.

Harzing, A-W., \& Pinnington, A.H. (Eds). (2011) International Human Resource Management. (3rd edition), London/Thousand Oaks, CA: Sage Publications. 
Gao, L., Liu, X., and Lioliou, E. (2015). 'Dynamic capabilities, managerial mindsets and the outcomes of internationalization: the case of Chinese state-owned enterprises'. In Demirbag, M and Yaprak, A. (Eds). Handbook of Emerging Market Multinational Corporations. Cheltenham: Edward Elgar Publishing, pp. $198-221$.

Gill, B. Huang, C-h \& Morrison, J. S. (2007). ‘Assessing China’s growing influence in Africa'. China Security, 3(3), 3-12.

Gill, B. and Reilly, J. (2007). 'The Tenuous Hold of China Inc. in Africa'. The Washington Quarterly, 30:3 pp.37-52;

Gugler, P. (2008). 'Chinese companies worldwide'. Vo. Accessed online 29 October 2013 from http://www.voxeu.org.aricle/how-are-Chinese-multinationalentrprises-different?

Harzing, A-W. 2001a 'An analysis of the functions of international transfers of managers in MNCs. Employee Relations, 23: 581-598.

Harzing, A-W. 2001b. 'Of bears, bumblebees, and spiders: The role of expatriates in controlling foreign subsidiaries'. Journal of World Business, 36(4): 336-379.

Heenan. D.A, and H.V. Perimutter, (1979) Multinational Organizational Development: A Social Architecture Perspective, Reading, Mass: AddisonWesley.

Horwitz, F.M. and Budhwar, P. (2015). (Eds). Handbook of Human Resource Management in Emerging Markets. Edward Elgar Publishing: Cheltenham UK \& Northampton MA. USA. Chap 1, pp 1-19. 
Horwitz, F.M (2012). 'Evolving human resource management in Southern African multinational firms: towards an Afro-Asian nexus'. The International Journal of Human Resource Management, 23 (14): 2938-2958.

Ip, P. K. (2009). 'Is Confucianism good for business ethics in China?' Journal of Business Ethics, 88: 463-76.

Jackson, T. (2002a). 'The Management of People Across Cultures: Valuing People Differently’. Human Resource Management. (Wiley: US), 41(4), 455-75.

Jackson, T. (2002b). International HRM: A Cross-cultural Approach, London: Sage,

Jackson, T. (2004). Management and Change in Africa. London: Routledge

Jackson, T. (2011) International Management Ethics: A Critical, Cross-cultural Perspective, Cambridge: Cambridge University Press.

Jackson, T. (2012). 'Postcolonial and organizational knowledge in the wake of China's presence in Africa: interrogating South-South relations'. Organization, 19(2), 181-204.

Jackson, T., Louw, L., and Zhao, S (2013). 'China in sub-Saharan Africa: implications for IHRM policy and practice at organisational level'. International Journal of Human Resource Management, 24 (13), pp. 2512-2533.

Jackson, T. (2014). 'Employment in Chinese MNEs: Appraising the Dragon's Gift to sub-Saharan Africa.' Human Resource Management, November-December, 53(6): 897-919.

Jacques, M. (2009). When China Rules the World: The Rise of the Middle Kingdom and the End of the Western World, London: Allen Lane.

Jie, L. (2010). 'The strategy of talent localization in multinational corporations'. Retrieved and accessed October 27, 2012 from: http://www.wenku.baidu.com/view/22a167ee4afe04a1b071def5.html, 
Kambhampati, U. S. (2004) Development and the Developing World, Cambridge: Polity.

Kamoche, K. and Harvey, M. (2006). 'Knowledge diffusion in the African context: An institutional theory perspective'. Thunderbird International Business Review, 48 (2) (2006), pp. 157-181.

Kamoche, K., Debrah, Y., Muuka, G and Horwitz, F.M. (2004). Managing Human Resources in Africa. London: Routledge.

Konapaske, R. and Werner, S (2005). 'US mangers' willingness to accept a global assignment'. International Journal of Human Resource Management, 16(7): 1159-1175.

Kamoche, K., and Newenham-Kahindi, A (2013)' Knowledge appropriation and HRM: The MNC experience in Tanzania'. In Newenham-Kahindi, A., Kamoche, K., Chizema, A and Mellahi, K (2013) (Eds). Effective People Management in Africa, London: Palgrave MacMillan, 97-126.

Kupka, B., Briscoe, D., Everett, A, (2013). 'Preparing expatriates for assignments to growing markets in Africa'. Paper presented at Annual Conference of the Pan Pacific Business Association, Johannesburg, June 5, pp.1-10.

Lazarova, M.B., and Thomas, D.C. (2012). 'Expatriate adjustment and performance revisited'. . In G.K Stahl., O, Bjorkman, \& M.M. Harris (Eds). Handbook of Research in International Human Resource Management, Cheltenham, UK \& Northampton MA. USA, Edward Elgar Publishing; pp.271-292.

Lee, L-Y and Sukoco, B. M. (2010) The effects of cultural intelligence on expatriate performance: the moderating effects of international experience, The International Journal of Human Resource Management, 21(7): 963-81

Li, X., Wang, J., and Liu, X. (2013). 'Can locally recruited R\&D personnel significantly contribute to multinational subsidiary innovation in an emerging economy?' International Business Review, 22:639-651. 
Lin, X., \& Farrell. (2013). 'The internationalisation strategies if Chinese state and private sector enterprises in Africa'. Journal of African Business, 14 (2), pp. 8595.

Malek, M.A and Budhwar, P (2013). 'Cultural intelligence as a predictor of expatriate adjustment and performance in Malaysia'. Journal of World Business, 48(2): $222-231$.

Mbigi, L (1997). Ubuntu: The African Dream in Management, Randburg, S. Africa: Knowledge Resources.

Meinert, D. (2013). 'Expatriate assignment in growth economies set to soar'. HR Magazine January, p.20.

Ministry of Foreign Affairs of The People's Republic of China (MOFA), (2006) China's African Policy, January 2006. http://www.fmprc.gov.cn/eng/zxxx/t230615.htm, accessed 12 December 2011. http://www.fmprc.gov.cn/eng/zxxx/t230615.htm, accessed 12 December 2011.

MOFCOM 2013. 'Chinese investment in Africa - how much?'. Posted by Brautigam, D., in 'China in Africa: The Real Story', pp.5-6.

Moran, R.T., Harris, P.R., \& Moran, S.V. (2012). Managing Cultural Differences. $\left(8^{\text {th }}\right.$ edition), Burlington, MA/Oxford, UK: Butterworth-Heinemann.

Mutabazi, E. (2002). 'Preparing African leaders'. Chapter 15 in C. B. Derr, S. Roussillon and F. Bournois (eds.) Cross-cultural Approaches to Leadership Development, Westport, CT: Quorum Books, 2002, pp. 202-223.

Nankervis, A., Cooke, F.L. Chatterjee, S., and Warner, M. (2014). New Models of Human Resource Management in China and India, London: Routledge, p.121.

Newenham-Kahindi, A., Kamoche, K., Chizema, A., and Mellahi, K (2013). Effective People Management in Africa. London: Palgrave MacMillan.

Osabutey, E. L. C., Williams, K., \& Debrah, Y. a. (2013). The potential for technology and knowledge transfers between foreign and local firms: A study 
of the construction industry in Ghana. Journal of World Business, 49(4), 560571.

Parmentola, A. (2011). 'Internationalization strategy of new Chinese multinationals'. International Journal of Management, 28 (1): 369-395.

Parry, E., Dickmann, M., Unite J., Shen, Y., and Briscoe J. (2015). 'Careers in Emerging Markets.' In Horwitz, F.M., and Budhwar, P. (Eds). Handbook of Human Resource Management in Emerging Markets. Edward Elgar Publishing: Cheltenham UK \& Northampton MA. USA, pp. 244-270.

Perlmutter, H.V. (1984). 'Building the Symbiotic Societal Enterprise: A Social Architecture for the Future'. World Futures, 19(3/4), 271-284.

Ping, D. (2004). 'Outward investment by Chinese MNCs: motivations and implications'. Business Horizons, 47 (3), pp. 8-16.

Qi, X. (2013). 'Talent Management in Chinese Multinational Corporations'. Masters Thesis, Vassan Finland: University of Applied Sciences.

Rostow, W. W. (1960) The Stages of Growth: A Non-Communist Manifesto, Cambridge: Cambridge University Press

Scullion, H., and Collings, D.G. (2006). International recruitment and selection'. In H. Scullion and D. G., Collings (Eds). Global Staffing. London/New York: Routledge, 59-86.

Shen, J. (2007). 'Approaches to International Industrial Relations in Chinese Multinational Corporations'. Management Revue, 18(4), 410-426.

Shen, J., and Edwards, V. (2013). International Human Resource Management in Chinese Multinationals. New York: Routledge Contemporary China Series.

Shen, S. (2009). 'A constructed (un)reality on China's re-entry into Africa: the Chinese online community perception of Africa (2006-2008)'. Journal of Modern African Studies, 47(3): 425-48. 
Shen J., Edwards, V. and Lee G. (2005). 'Developing an Integrative Human Resource Management Model: The Contribution of Chinese MNE's.' Asia Pacific Business Review. 11 (3), 368-384.

Shinn, D. H. (2006). 'Africa and China's Global Activism'. Paper Presented at the National Defence University Pacific Symposium China's Global Activism: Implications for U.S. Security Interests National Defence University Fort Lesley J. McNair June 20, 2006.

Sim, A.B. (2012). 'A comparative case study of the internationalization strategies of Malaysia, Singapore and Taiwanese firms'. Journal of Asian Business, 2493): 85-108.

Sirkin, H.L., Hemerling, J.W and Bhattacharya, A.K. (2008). Globality. New York: Business Plus.

Sparrow, P., Brewster, C., and Harris, H. (2012). Globalizing Human Resource Management ( $2^{\text {nd }}$ edition), London/New York: Routledge.

Stahl, G., K., Bjorkman, I., and Morris, H (2012). Handbook of Research in International Human Resource Management, Cheltenham UK \& Northampton USA: Edward Elgar Publishing.

Steers, R. M., Nardon, L., and Sanchez-Runde, C.J. (2013). Management across Cultures ( $2^{\text {nd }}$ edition), Cambridge UK: Cambridge University Press.

Stroh, L.K., Black, J.S., Mendenhall, M.E., and Gregersen, H.B (2005). International Assignments, Mahwah, NJ/London Lawrence Elbaum, Associates.

Teagarden, M.B. and Cai, D.H. (2009). 'Developmental lessons from China’s global companies', Organizational Dynamics, 38 (1), 73-81.

The Economist (2015). 'China in Africa - One among many'. January 17, pp.49-50.

The Economist. (2013). 'No need to dig'. 2 November, p. 78.

Thite, M. (2015). 'Human resource management in emerging market multinational companies'. In Horwitz, F.M. and Budhwar, P. (Eds) . Handbook of Human 
Resource Management in Emerging Markets, Edward Elgar Publishing: Cheltenham, Chap 5, pp. 97-121.

Thite, M. Wilkinson and Shah, D (2012), 'Internationalization and HRM strategies across subsidiaries in multinational corporations from emerging economies: A conceptual framework'. Journal of World Business, 47 (2) 251-258.

Tharenou, P (2002). 'Receptivity to careers in international work'. Australian Journal of Management, 27:129-136.

Tharenou, P. (2003). 'The initial development of receptivity to working abroad; Selfinitiated international work opportunities in young graduate employees'. Journal of Occupational and Organizational Psychology. 76:489-515.

Thomas, D.C., and Inkson, K (2007). 'Careers across cultures'. In Gunz, H., \& Peiperl, M. (Eds). Handbook of Career Studies. Thousand Oaks, CA: Sage Publishing, $451-470$.

Tung, R (1991). 'Selection and training of personnel for overseas assignments'. Columbia Journal of World Business, 16(1): 68-78.

Vance, C.M and Paik, Y. (2011). Managing a Global Workforce ( $2^{\text {nd }}$ edition), Armonk, NY: M.E. Sharpe.

Thomas, D.C., and Inkson, K (2007). 'Careers across cultures'. In Gunz, H., \& Peiperl, M. (Eds). Handbook of Career Studies. Thousand Oaks, CA: Sage Publishing, $451-470$.

Wang, D., Freeman., and Zhu, J.C. ' Personality traits and cross-cultural competence of Chinese expatriate managers: A socio-analytic institutional perspective'. International Journal of Human Resource Management, Online April 29, 2013: http://www.tandfonline.co./doi/abs/10.1080/09585192.2013.778314.

Webster, E (2001), 'Manufacturing Compromise'. In Baldoz, R., Koeber, C., and Kraft, P. (eds). The Critical Study of Work. Philadelphia: Temple University press, pp. 196-214. 
Wei, W. X. (2013). 'Editorial - Special Issue 'Chinese trade and investment in Africa'. Journal of African Business, 14 (2), pp. 72-74.

Wei, Y, and Wu, Y. (2015). 'How institutional distance matters to cross-border mergers and acquisitions by multinational enterprises from emerging economies and OECD countries'. In Demirbag, M, and Yaprak, A (Eds) (2015). Handbook of Emerging Market Multinational Corporations. Cheltenham: Edward Elgar Publishing, pp.111-136.

Wildau, G. (2015). 'China rail group signs $\$ 5.5$ bn in Africa deals'. Financial Times online (April 28), pp.1-2.

Wilkinson A, Wood, G and Demirbag, M (2014) (Eds) Special Issue (SI) on 'People Management and Emerging Market Multinationals'. Human Resource Management, 53 (6): 835-849.

Wood, G., and Horwitz, F.M. (2015) 'Theories and institutional approaches to HRM and employment relations in selected emerging markets'. In Horwitz, F.M and Budhwar, P. (eds) 2015. Handbook of Human Resource Management in Emerging Markets. Edward Elgar Publishing: Cheltenham UK and Northampton, MA. USA, Chap 2, pp. 19-42.

Wood, G., Dibben, P, Stride., C., and Webster, E. (2010). 'HRM in Mozambique homogenization, path dependence or segmented business system?' Journal of World Business, 46 (1): c31-41.

Yi-Chong, X. (2014) Chinese State-owned Enterprises in Africa: ambassadors or freebooters? Journal of Contemporary China, 23(89): 822-40.

Zhang, J., Wei, W.X., \& Zuanshi Liu. (2013). 'Strategic entry and determinants of Chinese private enterprises into Africa'. Journal of African Business, 14 (2), pp. 96-105.

Zhang, M., \& Edwards, C. (2007). 'Diffusing "best practice” in Chinese multinationals: the motivation, facilitation and limitations'. International Journal of Human Resource Management, 18(12), 2147-65. 
Zhu, J.S., Zhu, C.J., and De Cieri, H (2014). 'Chinese MNCs preparation for host country labor relations: An exploration of country-of-origin effect'. Human Resource Management, 53(6), Advance online publication, doi:10.1002/hrm.21613. 


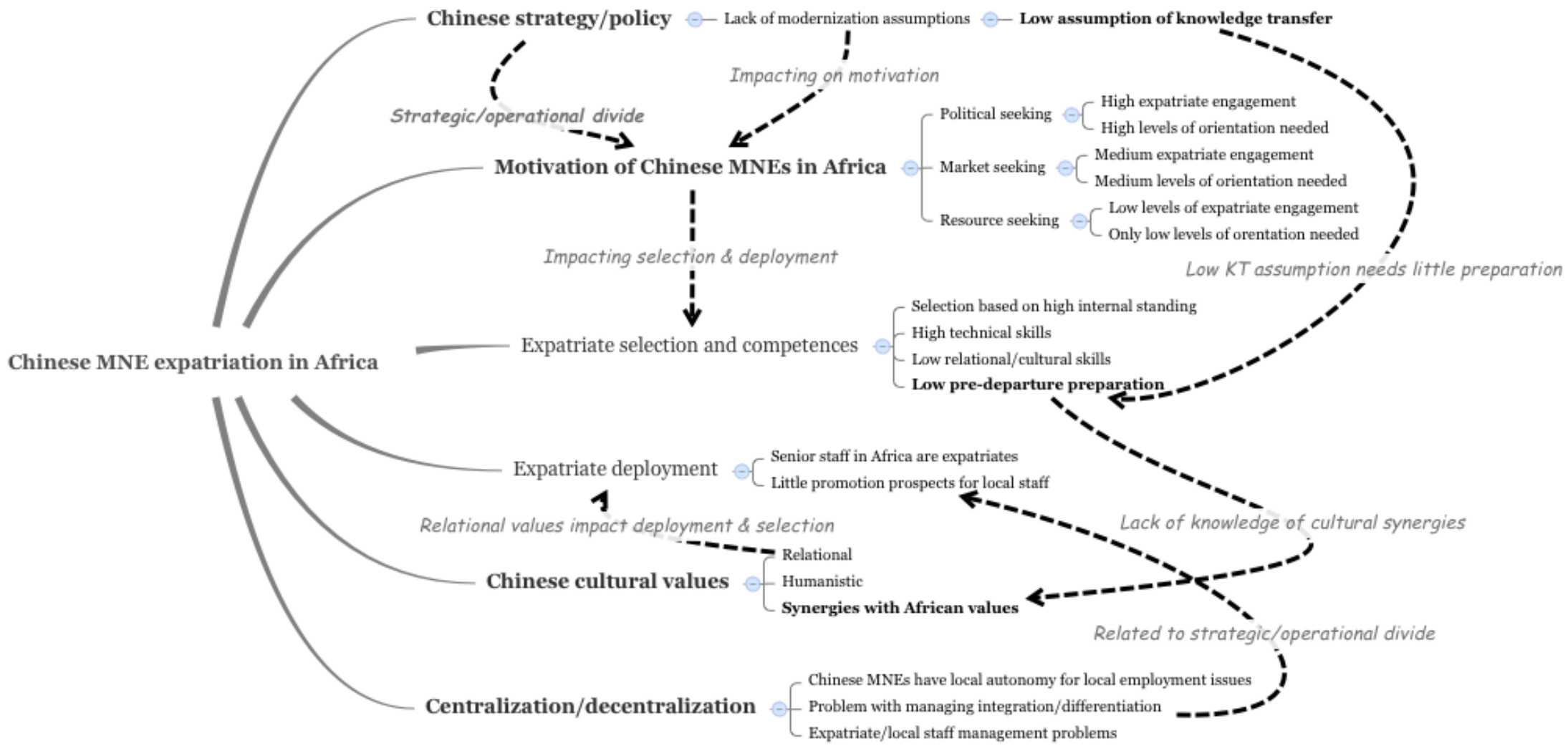

Figure 1 Conceptual Model of Chinese MNE expatriation in Africa 